\title{
PEMANFAATAN SOLAR CELL DENGAN PLN SEBAGAI SUMBER ENERGI LISTRIK RUMAH TINGGAL
}

\author{
Hasyim Asy’ari, Abdul Rozaq, Feri Setia Putra \\ Jurusan Teknik Elektro Fakultas Teknik Universitas Muhammadiyah Surakarta \\ J1. A. Yani Tromol Pos 1 Pabelan Kartasura 57102 Telp 0271717417 \\ Email: asy_98ari@yahoo.com
}

\section{ABSTRAKSI}

Sejak tahun 2013 Pemertinah menaikkan harga tariff dasar listrik sebesar 15\%, kenaikan dilakukan secara bertahap setiap 3 bulan sekali. Kenaikan tarif dasar listrik berlanjut di tahun 2014, awal mei 2014 semua pelanggan minimal 1300 Va dikenakan kenaikan sebesar 4\%, langkah ini diakibatnya semakin besar subsidi energi listrik oleh PLN yang mengalmai kerugian, salah satu penyebab kerugian PLN tersebut adalah mahalnya biaya operasional untuk pembelian bahan bakar pembangkit. Penggunaan energi terbarukan merupakan alternative untuk mengurangi permintaan energi ke PLN dan pengoptimalan potensi alam. Sel surya merupakan teknologi yang mengubah cahaya matahari menjadi energi listrik. Besarnya energi yang mampu dihasilkan oleh sel surya untuk kebutuhan rumah tangga merupakan tujuan dari penelitian ini, adapun metode penelitian ini adalah pengukuran energi yang mampu disuplai oleh energi yang dihasilkan oleh sel surya, penelitian ini menggunakan 2 buah modul sel surya dengan kapasitas masing-masing adalah 100 Wattpeak, Controller 12/24 Volt DC dengan kapasitas 60 A, Accumulator dengan kapasitas 100 Ah dan Inverter dengan kapasitas 500 Watt, Lampu DC Philips 5 Watt, 10 Watt, 13 Watt dan Lampu 5 buah SL 18 Watt.

Selama pengujian menunjukkan bahwa arus yang diproduksi paling tinggi terjadi sekitar jam 12.30, dengan nilai arus sebesar 13 A dan tegangan 14 Volt DC. Energi yang dihasilkan pada siang hari digunakan untuk mensuplai beban lampu mulai dari pukul 17.00 - 06.00 dengan rerata setiap malam energi yang dapat digunakan sebesar $1,027 \mathrm{Kwh}$.

Kata kunci: Sel surya; daya keluaran; Energi Terbarukan; Sistem Paralel.

\section{PENDAHULUAN}

Permintaan energi listrik akan tumbuh dengan rerata mencapai $6,5 \%$ setiap tahun sampai pada tahun 2020, kondisi tersebut dapat terlihat dari data konsumsi energi listrik setiap tahun selalu mengalami peningkatan sejalan dengan pertumbuhan ekonomi nasional. (Moch. Muchlis, 2003).

Penggunaan energi listrik di Indonesia terus mengalamai peningkatan, kondisi tersebut akan menimbulkan masalah jika dalam penyediaan energi listrik lebih kecil dari kapasitas yang dibutuhkan. Kebijakan yang diambil PLN (Perusahaan Listrik Negara) yang memiliki tanggung jawab dalam hal menyediakan energi listrik semakin menunjukkan bahwa energi listrik yang disediakan oleh PLN hanya memiliki kelebihan sekitar 3 GW. Jika PLN tidak segera menambah atau membangun pembangkit baru maka akan berdampak terhadap pelayanan energy listrik kepada konsumen, hal ini dapat mempengaruhi pertumbuhan ekonomi mengingat energi listrik merupakan kebutuhan fital dalam menjalankan kegiatan industry besar, menengah maupun, industry kecil dan sebagian peralatan rumah tangga.

Banyak langkah atau metode yang dilakukan untuk mengantisipasi permasalahan tersebut oleh berbagai kalangan antara lain instansi pemerintah, swasta dan peneliti. Upaya tersebut adalah mencari pembangkit yang energi primernya dari bahan alternative dan bahan yang tidak akan habis.

Penelitian ini berfokus pada pemanfaatan cahaya yang berasal dari matahari. Besarnya tingkat cahaya matahari yang menyinari bumi menjadi faktor utama dalam penelitian ini, setiap tahun cahaya matahari yang sampai di permukaan bumi adalah 3 x 1024 Joule, besarnya energi tersebut hampir sama dengan $1 \times 10^{4}$ Joule.

Pemanfaatan pembangkit dengan energi primer yang bersifat terbarukan memiliki posisi yang sangat penting dalam mengatasi permasalah kekurangan energi listrik, karena potensi energi terbarukan keberadaanya sangat besar sekali atau tidak terbatas. Selain itu penggunaan energi terbarukan, dalam hal ini 
photovoltaic atau sel surya merupakan jenis pembangkit listrik yang ramah lingkungan dan tidak menimbulkan polusi udara, suara seperti pada pembangkit konvensional, seperti pembangkit listrik tenaga uap.

Photovoltaic cells atau pembangkit listrik tenaga surya banyak dilirik oleh masyarakat mengingat teknologi ini dapat digunakan di berbagai lokasi yang banyak memiliki potensi sinar matahari, terutama di belahan bumi yang bersifat tropis. Di daerah tropis memiliki potensi kisaran $4,6 \mathrm{kWh} / \mathrm{m}^{2} /$ hari. Energi listrik yang diproduksi atau dihasilkan oleh teknologi photovoltaic sangat tergantung intensitas sinar matahari. Oleh sebab itu perlu ada sebuah treatment agar intensitasnya paling maksimal, serta cara pemanfaatan energi listrik dapat digunakan secara maksimal maka perlu adanya sistem hybrid dengan jala-jala listrik PLN.

Teknologi sel surya mampu menghasilkan daya maksimal sebesar 1000 watt $/ \mathrm{m}^{2}$ pada kondisi cuaca cerah disiang hari, hal ini dikarenakan pada saat itu intensitas cahaya matahari yang sampai ke permukaan bumi saat tengah hari adalah paling besar nilainya. Apabila piranti semikonduktor dengan luasan satu $\mathrm{m}^{2}$ memiliki efisiensi $12 \%$, maka daya yang dibangkitkan oleh modul sel surya sebesar 120 watt. Modul sel surya yang ada dipasaran memiliki efisiensi sekitar $4 \%$ hingga $16 \%$, perbedaan nilai efisiensi sangat tergantung dari bahan modul sel surya tersebut. Modul sel surya yang terbuat dari silicon Kristal memiliki efisiensi yang paling tinggi jika dibandingkan dengan material lain, akan tetapi dana untuk pembuatan modul tersebut paling mahal. Hal tersebut meupakan masalah tersendiri dalam hal implementasi modul sel surya secara massal. Perbandingan antara energi listrik yang dihasilkan dengan energi cahaya yang diterima dari pancaran sinar matahari oleh modul sel surya disebut dengan efisiensi. Pembangkit listrik tenaga surya (PLTS) menjelsakan bahwa efiseinsi konversi juga dipengaruhi oleh besarnya sinar matahari yang mampu dikonversi menjadi energi listrik (Awang R, 2008).

Sistem hybrid dengan prinsip kerja satu arah, yaitu beban hanya dipasok oleh salah satu pembangkit, ketika beban disuplai dengan energi yang dihasilkan oleh sel surya maka secara otomatis sambungan ke PLN dilepaskan dari beban atau beban tidak boleh disuplai oleh PLN, dan sebaliknya apabila listrik PLN sedang memberikan suplai listrik ke beban (hal ini dilakukan pada saat sel surya sudah tidak mampu memikul beban yang ditandai oleh tegangan keluaran accumulator 10,8 Volt), maka PLTS dilepaskan dari beban. Ketika pembangkit sel surya mampu mensuplai beban (kondisi tegangan keluaran accumulator mencapai 13,2 Volt) maka secara otomatis beban akan disuplai oleh sel surya dan PLN akan disconnect, hal itu dilakukan oleh switch pengatur secara otomatis (Jatmiko, 2011). Diagram sistem hybrid satu arah ditunjukkan pada gambar 1 .

Tegangan yang dihasilkan setiap sel pada sebuah modul sel surya sekitar 0,5 Volt pada 2A, pada kondisi kekuatan radiasi sinar matahari mencapai $1000 \mathrm{~W} / \mathrm{m}^{2}=$ "1 Sun" arus listrik (I) yang akan dihasilkan sekitar 30 $\mathrm{mA} / \mathrm{cm}^{2} / \mathrm{sel}$ pada modul sel surya. Faktor dari pengoperasian Sel surya agar didapatkan nilai yang maksimum sangat tergantung pada :

a. Ambient air temperature

Sel surya akan mampu beroperasi secara normal jika kondisi temperatur $25^{\circ} \mathrm{C}$, jika suhu sekitar modul sel surya berada pada kondisi diatas $25^{\circ} \mathrm{C}$, maka teganan open circuit akan mengalami penurunan, besarnya penurunan tegangan tersebut adalah $0,4 \%$ dari total tenaga yang dihasilkan atau akan mengecil $200 \%$ setiap kenaikan $10^{\circ} \mathrm{C}$. (Sumber: Solar Electricity, Lorenzo Eduardo.)

b. Radiasi matahari

Insolation solar matahari akan mempengaruhi nilai current (I) yang dihasilkan, radiasi matahari di permukaan bumi memiliki nilai yang bervariasi atau berbeda satu tempat dengan tempat yang lian, sehingga ini akan berpengaruh juga terhadap kinerja modul sel surya. 


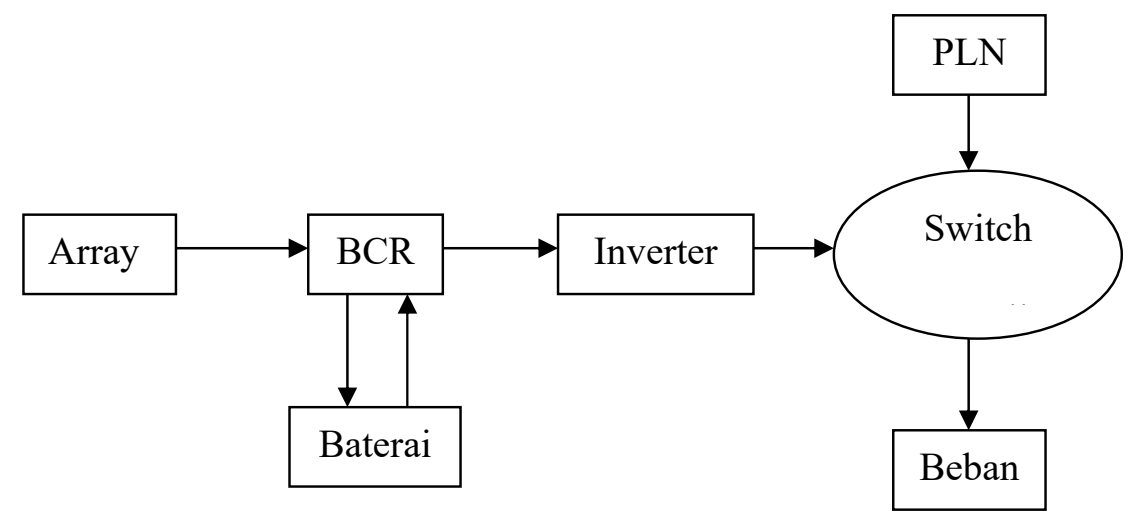

Gambar 1. Blok diagram sistem hybrid satu arah

c. Kecepatan angin bertiup

Kenaikan temperature pada sekitar permukaan sel surya memberi efek yang negative terhadap kinerja, untuk itu kecepatan angina pada area tersebut akan memberikan dampak yang positif karena mampu menurunkan temperature menuju kondisi suhu normal yaitu $25^{0} \mathrm{C}$.

d. Keadaan atmosfir bumi

Daya keluaran modul sel surya dipengaruhi oleh intensitas cahaya matahari yang mengenai pada permukaan sel, besar kecil nilai intensitas sinar matahari dipengaruhi banyak faktor, antara lain karena cuaca (berawan, cerah, hujan), karena kotoran (daun, asap, uap air, debu) yang menempel di permukaan sel.

e. Orientasi panel atau larik sel surya

Sudut yang terbentuk dari arah sumber sinar matahari dengan permukaan modul sel surya dapat mempengaruhi energi yang dihasilkan oleh sel surya tersebut. Sebagai guidline: untuk lokasi yang terletak di belahan Utara latitude, maka panel/deretan sel surya sebaiknya diorientasikan ke Selatan, orientasi ke Timur Barat walaupun juga dapat menghasilkan sejumlah energi dari panelpanel/deretan sel surya, tetapi tidak akan mendapatkan energi matahari optimum.

f. Posisi letak sel surya terhadap matahari.

Sebuah sel surya akan mampu menghasilkan energy yang paling optimal \pm 1 $\mathrm{x} 10^{3} \mathrm{watt} / \mathrm{m}^{2}$ atau sekitar $1 \mathrm{kilowatt} / \mathrm{m}^{2}$ yaitu jika kondisi sumber energy cahaya matahari berada pada posisi tegak lurus atau dengan sudut $90^{\circ}$.

\subsection{Arus dan Tegangan}

Penyusun sebuah materi adalah atom, atom terdiri dari banyak partikel sub-atom yang tersusun atas elektron, proton, dan neutron dalam berbagai gabungan. Elektron adalah muatan listrik negatif (-) yang paling mendasar. Elektron dalam cangkang terluar suatu atom disebut elektron valensi. Apabila energi eksternal seperti energi kalor, cahaya, atau listrik diberikan pada materi, elektron valensinya akan memperoleh energi dan dapat berpindah ke tingkat energi yang lebih tinggi. Jika energi yang diberikan telah cukup, sebagian dari elektron-elektron valensi terluar tadi akan meninggalkan atomnya dan statusnyapun berubah menjadi elektron bebas. Gerakan elektron-elektron bebas inilah yang akan menjadi arus listrik dalam konduktor logam. Gerak atau aliran elektron disebut arus ( $I)$, dengan satuan ampere.

Sebagian atom kehilangan elektron dan sebagian atom lainnya memperoleh elektron. Keadaan ini akan memungkinkan terjadinya perpindahan elektron dari satu objek ke objek lain. Apabila perpindahan ini terjadi, distribusi muatan positif dan negatif dalam setiap objek tidak sama lagi. Objek dengan jumlah elektron yang berlebih akan memiliki polaritas listrik negatif (-). Objek yang kekurangan elektron akan memiliki polaritas listrik positif $(+)$. Besaran muatan listrik ditentukan oleh jumlah elektron dibandingkan dengan jumlah proton dalam suatu objek. Simbol untuk besaran muatan elektron ialah $Q$ dan satuannya adalah coulomb. Besarnya muatan $1 \mathrm{C}=6,25 \mathrm{x}$ $10^{18}$ elektron.

Kemampuan muatan listrik untuk mengerahkan suatu gaya dimungkinkan oleh keberadaan medan elektrostatik yang mengelilingi objek yang bermuatan tersebut. Suatu muatan listrik memiliki kemampuan 
untuk melakukan kerja akibat tarikan atau tolakan yang disebabkan oleh gaya medan elektrostatiknya. Kemampuan melakukan kerja ini disebut pontensial. Apabila satu muatan berbeda dari muatan lainnya, di antara kedua muatan ini pasti terdapat beda pontensial. Satuan dasar beda pontensial adalah volt $(V)$. karena satuan inilah beda pontensial $V$ sering disebut sebagai voltage atau tegangan.

Daya listrik yang dihasilkan oleh sel surya merupakan hasil perkalian dari tegangan keluaran dengan banyaknya electron yang mengalir atau besarnya arus, hubungan tersebut ditunjukkan pada persamaan 1, sedangkan nilai rerata daya yang dihasilkan selama titik pengujian ditunjukkan pada persamaan 2.

$P=V I$

dengan:

$P=$ Daya keluaran (Watt)

$V=$ Tegangan keluaran (Volt)

$I=$ Arus (Ampere)

$$
P_{\text {rerata }}=\frac{P_{1}+P_{2}+\ldots+P_{n}}{n}
$$

dengan:

$P_{\text {rerata }}=$ Daya rata-rata $($ Watt $)$

$P_{1} \quad=$ Daya pada titik pengujian ke satu

$P_{2} \quad=$ Daya pada titik pengujian ke dua

$P_{n} \quad=$ Daya pada titik pengujian ke $\mathrm{n}$.

\section{METODE PENELITIAN}

Bahan-bahan yang digunakan pada penelitian ini adalah:

a) Dua buah Panel sel surya dengan kapasitas masing-masing 100 Wattpeak (Wp) digunakan untuk mengkonversi cahaya matahari menjadi energy listrik

b) Kontroller 60 A merk View Star 12/24 Volt DC

c) Accumulator $12 \mathrm{~V}, 100 \mathrm{Ah}$

d) Inverter 500 Watt e) Lampu LED Philips 5 Watt, 10 Watt, 13 Watt dan 5 Buah Lampu SL @ 18 Watt

Perakitan modul sel suray dan pembuatan jaringan instalasi listrik penerangan diperumahan merupakan bagian dari tahapan penelitian ini, memonitoring hasil daya yang dihasilkan oleh system sel surya bisa dilihat setiap detik melalui display pada kontroler, adapun parameter yang mampu ditampilkan adalah besarnya tegangan, arus, temperature pada sel surya, tegangan dan arus masuk maupun keluar pada accumulator. Secara detail diagram alir penelitian tersebut ditunjukkan pada gambar 2 .

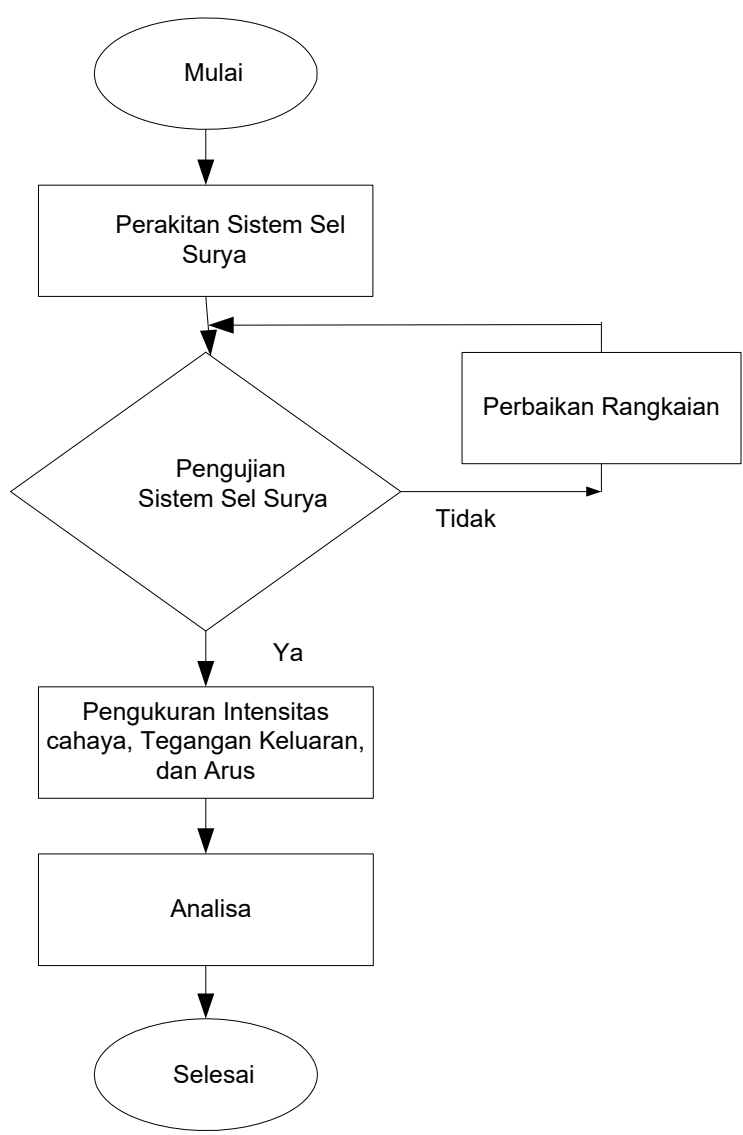

Gambar 2. Diagram Alir Penelitian 


\section{HASIL DAN ANALISA}

Penelitian ini merupakan suatu langkah untuk mengetahui hubungan intensitas cahaya matahari yang mampu dikonversi oleh sel surya menjadi energy listrik serta kapan energy tertinggi yang dihasilkan oleh sel surya. Hasil pengujian secara detail ditunjukkan pada tabel 1, 2, dan tabel 3 .

Tabel 1. Hasil Pendataan Kebutuhan Energi Sebelum Menggunakan Sel Surya ( 25-9-2013).

\begin{tabular}{cccl}
\hline No & Tanggal & $\begin{array}{c}\text { Konsumsi } \\
\text { Energi }\end{array}$ & \multicolumn{1}{c}{ Keterangan } \\
\hline 1 & $25-9-2013$ & - & Awal data penelitian, referensi 106,06 KWH \\
2 & $26-9-2013$ & $2,64 \mathrm{KWH}$ & Konsumsi energi selama 24jam $(106,06-103,40)$ \\
3 & $30-9-2013$ & $10,38 \mathrm{KWH}$ & Konsumsi energi selama 96jam $(103,40-93,02$ \\
4 & $1-10-2013$ & $2,34 \mathrm{KWH}$ & Konsumsi energi selama 24jam $(93,02-90,68)$ \\
5 & $2-10-2013$ & $2,96 \mathrm{KWH}$ & Konsumsi energi selama 24jam $(90,68-87,72)$ \\
6 & $3-10-2013$ & $3,57 \mathrm{KWH}$ & Konsumsi energi selama 24jam $(87,72-84,15)$ \\
7 & $4-10-2013$ & $3,67 \mathrm{KWH}$ & Konsumsi energi selama 24jam $(84,15-80,48)$ \\
8 & $5-10-2013$ & $2,71 \mathrm{KWH}$ & Konsumsi energi selama 24jam $(80,48-77,77)$ \\
9 & $6-10-2013$ & $2,80 \mathrm{KWH}$ & Konsumsi energi selama 24jam $(77,77-74,97)$ \\
10 & $7-10-2013$ & $2,18 \mathrm{KWH}$ & Konsumsi energi selama 24jam $(74,97-71,99)$ \\
11 & $8-10-2013$ & $3,08 \mathrm{KWH}$ & Konsumsi energi selama 24jam $(71,99-68,91)$ \\
12 & $9-10-2013$ & $2,66 \mathrm{KWH}$ & Konsumsi energi selama 24jam $(68,91-66,25)$ \\
13 & $10-10-2013$ & $2,80 \mathrm{KWH}$ & Konsumsi energi selama 24jam $(66,25-63,45)$ \\
14 & $11-10-2013$ & $2,72 \mathrm{KWH}$ & Konsumsi energi selama 24jam $(63,45-60,73)$ \\
15 & $12-10-2013$ & $2,49 \mathrm{KWH}$ & Konsumsi energi selama 24jam $(60,73-58,24)$ \\
\hline
\end{tabular}

Tabel 2. Hasil Pendataan Setelah Menggunakan Sel Surya (10 - 2 - 2014)

\begin{tabular}{cccc}
\hline No & Tanggal & $\begin{array}{c}\text { Konsumsi } \\
\text { Energi }\end{array}$ & \multicolumn{1}{c}{ Keterangan } \\
\hline 1 & $10-2-2014$ & - & Sebagai data awal referensi pada KWH meter 55,36KWH \\
2 & $11-2-2104$ & $2,6 \mathrm{KWH}$ & Konsumsi energi selama 24jam $(55,36-52,76)$ \\
3 & $12-2-2014$ & $2,88 \mathrm{KWH}$ & Konsumsi energi selama 24jam $(52,76-49,88)$ \\
4 & $13-2-2014$ & $3,08 \mathrm{KWH}$ & Konsumsi energi selama 24jam $(49,88-46,80)$ \\
\hline
\end{tabular}




\begin{tabular}{cccc}
\hline No & Tanggal & $\begin{array}{c}\text { Konsumsi } \\
\text { Energi }\end{array}$ & \multicolumn{1}{c}{ Keterangan } \\
\hline 5 & $14-2-2014$ & $2,85 \mathrm{KWH}$ & Konsumsi energi selama 24jam $(46,80-43,95)$ \\
6 & $15-2-2014$ & $3,08 \mathrm{KWH}$ & Konsumsi energi selama 24jam $(43,95-40,87)$ \\
7 & $16-2-2014$ & $3,06 \mathrm{KWH}$ & Konsumsi energi selama 24jam $(40,87-37,81)$ \\
8 & $17-2-2014$ & $2,9 \mathrm{KWH}$ & Konsumsi energi selama 24jam $(37,81-34,91)$ \\
9 & $18-2-2014$ & $3,17 \mathrm{KWH}$ & Konsumsi energi selama 24jam $(34,91-31,74)$ \\
\hline
\end{tabular}

Tabel 3. Hasil Kebutuhan Penerangan Setelah Menggunakan Sel Surya (21 - 2 - 2014)

\begin{tabular}{|c|c|c|c|}
\hline No & Tanggal & Beban & Konsumsi Energi \\
\hline 1 & $21-2-2014$ & Beban Lampu 118 W Selama 10 Jam & $1180 \mathrm{Wh}$ \\
\hline 2 & $22-2-2014$ & Beban Lampu $100 \mathrm{~W}$ selama 10 jam & $1000 \mathrm{Wh}$ \\
\hline 3 & $23-2-2014$ & $\begin{array}{l}\text { Beban Lampu } 77 \text { W selama } 10 \text { Jam } 30 \\
\text { menit }\end{array}$ & $808 \mathrm{Wh}$ \\
\hline 4 & $24-2-2014$ & Beban Lampu $100 \mathrm{~W}$ selama 9 Jam & $900 \mathrm{Wh}$ \\
\hline 5 & $25-2-2014$ & Beban Lampu 118 W Selama 9 Jam & $1062 \mathrm{Wh}$ \\
\hline 6 & $26-2-2014$ & Beban Lampu 118 W Selama 10 Jam & $1180 \mathrm{Wh}$ \\
\hline 7 & $27-2-2014$ & Beban Lampu 118 W Selama 9 Jam & $1062 \mathrm{Wh}$ \\
\hline
\end{tabular}

Dari data tabel 1 dan 2 dapat ditentukan juga rata-rata konsumsi energi harian setelah sistem paralel sel surya dan PLN di terapkan.

Ekata - rata konsumst anorgt $=\Sigma^{\prime} E_{b}$

$$
\begin{aligned}
& \sum E_{b}=\frac{E_{t}+E_{2}+\cdots+E_{8}}{8} \\
& \Sigma E_{b}=\frac{28,62}{8}
\end{aligned}
$$

\section{$\sum E_{b}=2,95 \mathrm{KWF}$}

\section{KESIMPULAN}

Beberapa kesimpulan dari penelitian ini adalah pemanfaatan sel surya dengan kapasitas 200 Wattpeak mampu menghasilkan energy listrik untuk mensuplai beban penerangan, rerata energy yang dimanfaatakan adalah 1027 Watt Jam atau 1,027 Kwh.

\section{DAFTAR PUSTAKA}

Amien, R, dkk, 2008, Optimalisasi Pemanfaatan Sel Surya Pada Bangunan Komersial secara Terintegrasi sebagai Bangunan Hemat Energi, Seminar Nasional Sains dan Teknologi-II 2008, Lampung.

Berahim, H, 1994, Pengantar Teknik Tenaga Listrik, Andi Offset, Yogyakarta.

Hasyim Asy'ari, Jatmiko, Angga, Intensitas Cahaya Matahari terhadap Daya Keluaran Sel Surya, RAPI XI, UMS, Surakarta.

Jatmiko, Hasyim, 2011, Pemanfaatan Sel Surya dan Lampu LED untuk 
Perumahan, Semantik, UDINUS, Semarang

Juhari AB, dkk, 2009, Optimization of PVWind-Hydro-Diesel Hibrid Sistem by Minimizing Excess Capacity, European Journal of Scientific Research.

Kamaruzzaman. S, Mohd. Y, 2005, Performance of a Photovoltaic Diesel Hibrid Sistem in Malaysia, ISESCO Science and Technology Vision.
Martin, San,..., Hybrid Technologies: Fuel Cells and Renewable Energies.

Tumiran, 2002, Kualitas Energi Listrik Menyongsong Pembahasan RUU Ketenagalistrikan, Majalah Energi, Edisi 16 (Juni-Agustus 2002), Pusat Studi Energi UGM, Yogakarta

Wang, Cheisang, 2008, Power Management of a stand-alone Wind/Photovoltaic/Fuel Cell Energi System, IEEE Transaction on Energi Conversion, Vol 23 No.3. 